\title{
PLANNING AND MANAGEMENT CHALLENGES OF TOURISM IN NATURAL PROTECTED AREAS IN BAJA CALIFORNIA, MEXICO
}

\author{
R. ROJAS-CALDELAS ${ }^{1}$, C. PEÑA-SALMÓN ${ }^{1}$, A.L. QUINTANILLA-MONTOYA ${ }^{2}$, \\ A. ARIAS-VALLEJO ${ }^{1} \&$ E. CORONA-ZAMBRANO ${ }^{1}$ \\ ${ }^{1}$ Universidad Autónoma de Baja California, México. \\ ${ }^{2}$ Universidad de Colima, Mexico.
}

\begin{abstract}
The continued exploitation of natural resources has enforced governments to establish regulations through different legal instruments to encourage its land use suitably for development and conservation by means of efficient planning and management. However, there is always the dilemma between economic interests and environmental and social ones when developing tourism in natural protected areas (NPAs). The purpose is to analyse the constraints that tourism faces in natural areas from three perspectives of interest groups. Firstly, from a federal economic development project "Nautical Stations" promoted by the government and tourism investors; secondly, from environmental institutions devoted to the protection of natural areas; and thirdly, from local residents in order to satisfy their social, economic and environmental needs. The methodology has been based on literature review to support the legal and regulatory framework on urban land use planning: NPAs and federal and state tourism development policies in Mexico and Baja California as well as technical reports and surveys developed by academic institutions assessing the welfare conditions of local residents before and after the application of environmental and tourism policies in the region. Lastly, results show that the nautical stations project had poor economic benefits with respect to expectations of regional economic growth. Thus, the nautical tourist model had not been successful due to environmental regulations imposed over the region.

Keywords: ecological tourism, natural protected areas, rural tourism, rural development, sustainable development.
\end{abstract}

\section{INTRODUCTION}

The regional development project focused on nautical tourism called "Nautical Stations" is an idea that had been born in the 1970s under the name of "Tourist Marine Stations" by the Commission for Tourism Development in the Gulf of California, México. Later, in 1998, the proposal was restarted to boost tourism in the region Sea of Cortes, through the Tourism Development National Fund (FONATUR) to provide ports, roads and air infrastructure to enhance international tourism. In addition, the purpose of this project was to identify suitable sites and conduct planning processes to acquire land reserves and economic resources to implement it [1]. A new federal administration in 2000 had taken the management and had promoted it as a national mega project, supported by the Ministry of Tourism, specifically through FONATUR to detonate different regions of the country. Such was the case of the Nautical Stations of the Sea of Cortes in northwestern Mexico; Costa Maya Palenque-Agua Azul waterfalls in the southeastern region; and on the central west coast, the New Integrally Planned Center in Nayarit [2]. 
The project had embraced a wide territory where five states were involved: Nayarit, Sinaloa, Sonora, Baja California and Baja California Sur (Fig. 1), sharing the Sea of Cortes and 15 coastal municipalities, integrating 20 nautical stations and a land bridge linking the Pacific Ocean with the Sea of Cortes (Santa Rosalillíta and Bahía de los Angeles) [1, 3].

Under a strategic planning model, the project was conceived as comprehensive, inclusive, participatory and long term, looking to detonate the region and to bring out social, economic and environmental beneficial impacts. It also had the purpose to promote low impact nautical tourism and the protection of natural and cultural resources of the Sea of Cortes. Thus, tourism would be oriented towards those segments that supported the conciliation of development and the protection of environment and culture such as eco-tourism, rural tourism, adventure tourism and health tourism. To achieve this, it was deemed necessary to create an infrastructure to support, organize and regulate tourism in the region.

The project was planned on four stages: The first was planning, which had integrated market studies, environmental feasibility, technical and financial viability and acquainting socio-economic benefits among stakeholders. The second was the take-off, focusing on the use of the existing infrastructure of ports from 2004 to 2006. The third was growth, which involved the expansion and follow up on the abandoned nautical stations network from 2007 to 2012. The fourth was consolidation of the project and the overall operation from 2013 onwards [3].

The management of the megaproject had demanded compliance with law and regulations for terrestrial and marine natural resources set in ecological planning ordinances and environmental impact statements of infrastructural projects, in addition to the compliance with the preparation of urban planning ordinances and regulations of coastal human settlements and the environmental impact statements of tourism projects.

To accomplish this task, coordination and concurrence of different levels of governments was required: municipal, state and federal who shared the territory. The main defiance was to have located a tourist marina project in Baja California where nearly half of the territory was a natural protected area (NPAs). The region has been known for its richness of marine and
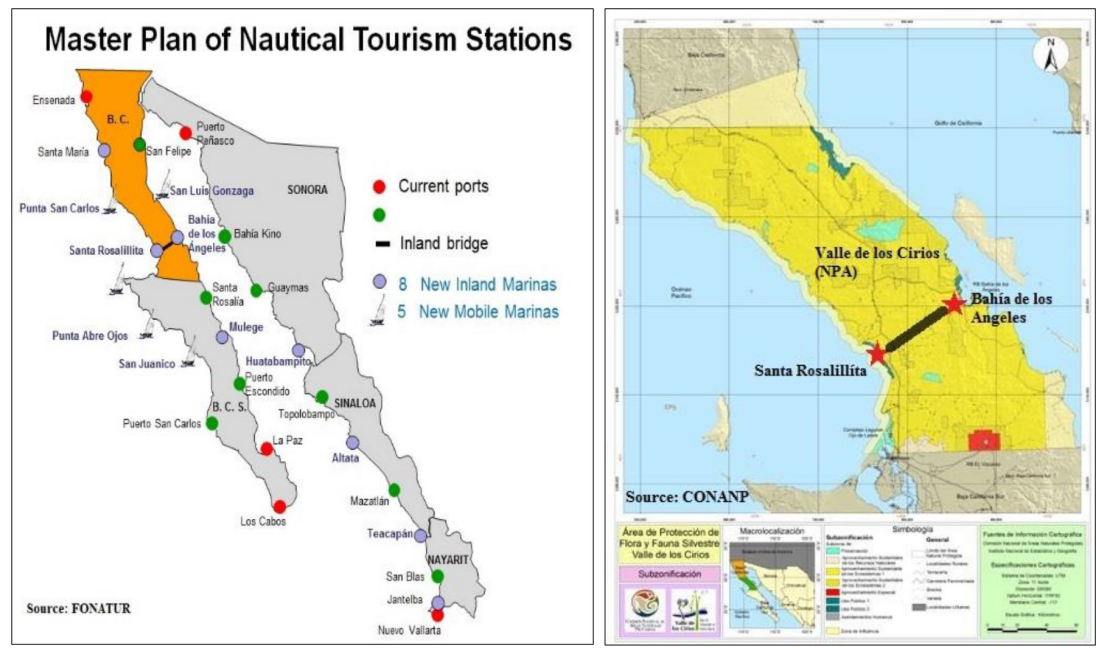

Figure 1: Location of Nautical Tourism Stations and Valle de los Cirios NPA. 
terrestrial wildlife, all of them protected by federal law and included in the National System of NPA, which is worth visiting for its cultural heritage values. Within the state, two new tourist marinas were planned to be set in an NPA Valle de los Cirios in a rural community Santa Rosalillíta in the Pacific Ocean and in Bahía de los Angeles in the Sea of Cortes, both working as a land bridge (Fig. 1). Besides, three tourist routes were also planned: Santa Rosalillita-Bahía de los Ángeles, Cataviñá-Guerrero Negro and Bahía de los Ángeles-Bahía de las Animas [3].

Thus, the paper has three main purposes: firstly, to show the evolution of a national strategy to promote a nautical tourism experienced throughout four federal administrations; secondly, to analyse the legal basis which had led to the implementation of land use regulations for human settlements and environmental protection; and thirdly, to display social and environmental impacts as a result of tourism development promoted in NPA by tourism developers, authorities responsible for the management of protected areas, and from local residents in order to satisfy their social, economic and environmental needs. The work has been based on literature review from different sources from 1995-2015.

\section{LEGAL FRAMEWORK AND PLANNING INSTRUMENTS}

Once the federal government had announced the mega tourism project "Nautical Stations" through FONATUR in early 2000, the machinery to develop and implement urban land use plans for small towns for the acquisition of land reserves for real estate business was launched in the State of Baja California and tourism infrastructure was introduced. Among them were the land bridge and marinas in Santa Rosalillíta-Bahía de los Ángeles, projects that could have been changed the dynamics of low impact tourism by one of high impact, oriented to real estate and tourism investors, with minimal participation of local entrepreneurs.

This initiative resulted in the development of general guidelines [4] by which, in the absence of urban development programs [6], and based on Article 20 of the Law on Urban Development (1994), the State of Baja California has authorized land uses, location and construction of buildings, modifications or introduction of basic infrastructure services in small towns (Table 1) as well as actions of urbanization in the proposed draft that would regulate land use in locations to be affected by the project, including those in Bahía de los Ángeles [4]. All this had happened in a region that was already declared a protected area since the 1980s under the category of Area of Forest Protection and Wildlife Refuge and re-categorized in 2000 as Protection Area of Flora and Fauna [5], as was the case with the Gulf Islands, which were enacted since 1978 and re-categorized in 2000 [6] (Table 2).

The pressure over this region of great terrestrial and marine ecological values, had encouraged the National Commission of NPAs (CONANP) to enact and protect other sensitive areas in the region affected by nautical tourism with respect to Bahia de los Ángeles, Canal de Ballenas y Salsipuedes in 2007 [7] and the Archipelago of San Lorenzo in 2005 [8]. Thus, they had to accelerate the work for the preparation, achievement of community consensus and the publication of management plans and programs for ecological and environmental protection from 2005 to 2015, as seen in Table 2.

\section{TOURISM}

Traditional tourism in Mexico that has been linked to sun and sand, where investment in infrastructure has been developed as well as international tourism of main destinations such as Acapulco, Puerto Vallarta, Cancun, Ixtapa, Los Cabos and Riviera Maya have been promoted. During 2012, the construction of hotel rooms was concentrated in eight major 
Table 1: Tourism and urban development plans.

Ecological, tourism and urban development plans and programmes
Decrees (PO: Official Periodical of

Baja California and DOF: Official

Periodical of the Federation)
State Ecological Management Plan of Baja

California [10]

Urban Development Guidelines for Bahía de los

Ángeles and Santa Rosalillíta [4]

Urban Development Guidelines for the Tourist

Corridor Bahía de los Ángeles [11]

Marine Ecological Management Plan of the Gulf of California [25]

Ecological Coastal Management Program of Puertecitos-Paralelo $28^{0}$ [13]

Regional Urban, Tourist and Ecological

Development Program for the Coastal Corridor

San Felipe-Puertecitos-Bahía de los Ángeles [14]
PO: 8/09/1995.

Updated PO: $7 / 10 / 2013$.

Updated PO: 3/07/2014.

PO: $11 / 06 / 2003$

PO: $19 / 08 / 2005$

DOF: $15 / 12 / 2006$

PO: $19 / 10 / 2007$

PO: $27 / 12 / 2010$

Table 2: Natural protected areas.

\begin{tabular}{|c|c|c|c|}
\hline Program & $\begin{array}{l}\text { Protection } \\
\text { Category }\end{array}$ & $\begin{array}{c}\text { Creation/Re-caterorization/ } \\
\text { Surface }\end{array}$ & Management \\
\hline $\begin{array}{l}\text { Isles of the Gulf of } \\
\text { California }[6,15]\end{array}$ & $\begin{array}{l}\text { Protection Area } \\
\text { of Flora and } \\
\text { Fauna }\end{array}$ & $\begin{array}{l}\text { Decree: DOF: 02/08/1978 } \\
\text { Re-categorization } \\
\text { 07/06/2000. Surface: } \\
374,553.63 \text { ha }\end{array}$ & $\begin{array}{l}\text { Management } \\
\text { Program DOF: } \\
\text { 17/04/2001 }\end{array}$ \\
\hline $\begin{array}{l}\text { Bahía de los Ángeles, } \\
\text { Canales de Ballenas y } \\
\text { de Salsipuedes }[7,16]\end{array}$ & $\begin{array}{l}\text { Biosphere } \\
\text { Reserve }\end{array}$ & $\begin{array}{l}\text { Decree: DOF: 05/06/2007 } \\
\text { Marine Surface: } \\
387,956.88 \text { ha }\end{array}$ & $\begin{array}{l}\text { Management } \\
\text { Program DOF: } \\
\text { 05/11/2013 }\end{array}$ \\
\hline $\begin{array}{l}\text { Valle de los Cirios } \\
{[5,17]}\end{array}$ & $\begin{array}{l}\text { Protection Area } \\
\text { of Flora and } \\
\text { Fauna }\end{array}$ & $\begin{array}{l}\text { Decree: DOF: 02/06/1980 } \\
\text { Re-categorization: DOF } \\
\text { 07/06/2000 Surface: } \\
\text { 2,521,987.61 ha }\end{array}$ & $\begin{array}{l}\text { Management } \\
\text { Program DOF: } \\
\text { 02/04/2013 }\end{array}$ \\
\hline $\begin{array}{l}\text { Archipiélago de San } \\
\text { Lorenzo }[8,18]\end{array}$ & National Park & $\begin{array}{l}\text { Decree: DOF 25/04/2005 } \\
\text { Marine surface: } \\
58,442.80 \text { ha }\end{array}$ & $\begin{array}{l}\text { Management } \\
\text { Program DOF: } \\
\text { 20/01/2015 }\end{array}$ \\
\hline
\end{tabular}


destinations: Ciudad de México, Riviera Maya, Cancún, Acapulco, Guadalajara, Los Cabos, Monterrey y Puerto Vallarta [9]. Excepting for Los Cabos, most of them are located in coastal areas with humid warm climates, with public facilities, roads, airports and marine ports infrastructure. Besides, they are either in large- and medium-sized cities or closer to them, with high levels of urbanization and with ample provision of goods and services to the local as well as tourist population.

In order to diversify tourism, the federal government has promoted alternative tourism, such as nature tourism, and thereby gives small towns and regions an opportunity to explore new market niches. It considers that as visitors are in contact with nature and the culture of communities they contribute to the conservation of natural and cultural resources. Ecotourism, adventure tourism and rural tourism are all considered part of this approach [9].

"Valle de los Cirios" located in the peninsula of Baja California, México, which has been taken as the case study, has been an NPA since 1980, and an arid region with relative isolation from major urban centers within the state and the country, poor infrastructure of roads and scarce air and land transportation means [19]. Conversely, its valued wildlife and cultural resources, has made this region an ideal place for those who like or study nature and desert environments. Main tourism destinations are Cataviña and Bahía de los Ángeles, while Santa Rosalillíta is a fishing settlement. These small towns are placed in a category of rural settlements, because they have lesser than 2500 inhabitants; this condition constraints urbanization as well as falls short in providing goods and services to local residents and tourist visitors [20]. Under this context, Bahía de los Ángeles would become the most affected settlement in the region since the launching of the nautical tourism stations project.

Bahía de los Angeles is a coastal rural settlement in front of the Sea of Cortes, which began as a fishing camp, fishing being its primary economic base. However, over time the residents have faced various obstacles among which are [21] hot weather conditions during summer and seasonality of fishing; low income; high risk for fishermen and changes in national and international policies, especially the lack of institutional support to small producers. In terms of competitiveness, small entrepreneurs have been left out, due to high costs of production as compared to large permit holders. From this time, tourism has been developed as a complementary activity to fishing, not only because of Bahía de los Angeles' marine resources, but also because of the efficient resource management of flora, fauna, geological interest of its surroundings, the beauty of its landscapes and the knowledge of its cultural heritage, where all these have offered potentialities to be developed, but under regulation, because this NPA has high rates of fragility in its ecosystems [22].

The origins of tourism in this town according to Zizumbo and Lopez-Casillas and Daneman [21, 23], can be traced to the 1940s, where the main travelers were Americans, who given the difficult conditions of town accessibility, have used private air plane services of low passenger capacity. By the mid-1950s a private airline had weekly trip services coming from San Diego, California. This has led to the creation of small businesses committed to providing tourist services. The same authors have indicated that in the 1970s the settlement offered lodging, fueling, food and beverages and guide services. Other people were employees, merchants, drivers and mechanics on a small scale. At the same time, it was deemed necessary to provide road access to the settlement from the main road called Transpeninsular to attract tourism travelling with motor caravans (RV's) and, consequently, some residents were driven to set RVs parking lots, camping sites and hotels. After this decade, in the 1980s, construction process to build small houses along the beach came into force, for those visitors wanting to spend the winter season in a warmer climate. From the 1990s up to 2010 tourism has grown slightly, compared to the Nautical Stations Project's estimations of growth. 
Common visitors attending Bahía de los Ángeles could be grouped into three: the first group, comprising young people looking for adventure in natural environments as well as Mexican and American students arriving for the purpose of marine and terrestrial research; the second group, consisting of sport fishing and sailboats fans; and the third group, represented by seniors, seeking contact with nature and a peaceful environment to spend their retirement. The group with major economic spill over local residents has been that for sport fishing mainly practiced by Americans who have huge demands for lodging, food, boats rental and hiring guides [21], whereas a lesser demand is from those with sailing boats who regularly have everything in their boats, as well as from tourists arriving in RVs. The rest of the visitors stay in the settlement from three to five days and are local tourists from Baja California who usually arrive during holiday periods. Tourism activities are focused on sun and sand, tours to missions and cave paintings, whale watching, diving, visiting the islands and coastal tourist areas, kayak tours, hiking, visiting mines and observing wildlife.

Nowadays, the State of Baja California has a Tourism Observatory, created with the purpose of monitoring tourism activities in main destinations, and providing some statistical information about the performance of economic activity around tourism. According to this source it seems that Bahía de los Ángeles maintains a low flow of visitors. In 2014, this settlement received 600 visitors during Easter holidays, of which 95 percent were from Baja California, focused on sun and sand tourism and a lesser percentage practicing diving and hiking [24].

\section{TOURISM CHALLENGES IN NPA}

The Nautical Tourism Stations project had generated great economic expectations among investors and governmental authorities, whose effects could have produced positive impacts on the quality of life of rural communities living in this region. Despite the planning efforts and public investments done by authorities involved to create better conditions to implement the project by means of land use regulation, NPA management plans and programmes, paved roads, introduction of electricity, and the construction of marinas, the project faced several obstacles. Among them were: first, mistrust and resistance of local communities to the implementation of the project; second, the suspension and abandonment of it on several occasions for economic reasons; third, restrictions imposed by management plans and the surveillance of environmental authorities tracking environmental impacts of tourism in NPA (due to their condition of fragility and low carrying capacity ecosystems); and fourth, pressure exerted by regional and national environmental groups [29].

It is almost 15 years since the project has started, but achievements have been few and the project has not moved beyond the first stage as it had to deal with numerous financial difficulties; however, authorities are still confident that the project could be rescued, which means that they have not learnt the lesson yet.

In the case of Baja California, the municipal management structure for these small towns is through delegations; they do not generate or have external financial resources to maintain adequate public services for small population (lower than 2500 inhabitants). Besides, these communities are farther from the major urban center of the municipality located in Ensenada, around 500 kilometers away from Bahia de los Angeles, where suburban transport service are often scarce and irregular in frequency [20]. The nautical stations project should also required investment to strengthen governance in small towns, as well as the improvement of telecommunications infrastructure and so also new air and land transportation services [19]. Table 3 summarizes the constraints the region faces, seen through main stakeholders, where win-win agreements have not been reached. 
Table 3: Tourism challenges by stakeholders in NPA.

FONATUR: Tourism development promoters [1]

- Natural and cultural resources are not prepared to meet tourist requirements

- Put in value natural resources, restoration, improvement and necessary maintenance to cater to tourists.

- Difficult access to places and thus need to improve roads

- Small towns with reduced populations

- Deficit of telecommunications networks

- Lack of water and energy

- Lack of accommodation and restaurants

- Preference for sun and beach places

- Recognize the fragility of ecosystems

CONANP: Conservation promoters [27]

- Limited qualified human resources for the management and development of tourism in NPAs.

- Lack of intra- and inter-institutional coordination for development and tourism management at the local, regional and national level.

- No homogenous application of planning and management tools for developing tourism in NPAs.

- Insufficient budget for management and development of tourism.

- Insufficient and / or inadequate infrastructure to support tourism to minimize negative impacts.

- Lack of clear investment criteria for infrastructure and tourism projects in NPA.

- Degradation of tourist attractions from planning processes and by unplanned developments, as well as overcrowding or by wrong use of places.

- Current environmental deterioration of suitable tourism areas in the country, caused by productive activities, urban development and overexploitation of some natural and cultural resources.

- Mexico has positioned itself as a massive tourism destination of sun and sand.

- Public policies orientated to development that does not encourage conservation as a key hub of the country.

- Institutional disarticulation that does not allow integrated planning and public financing oriented to priority needs.

CONABIO: Biodiversity promoters [28]

- Development of tourism infrastructure of high impact

- Pressure by poor tourism practices

- Pollution (water and soil)

- Unplanned exploitation of forest resources (timber and non-timber)

- Land speculation for sale of land plots, mining and tourism development projects

- Erosion and soil degradation

- Overexploitation of water bodies and aquifers 
Table 3: (Continued)

Community: Residents of Bahía de los Ángeles [21].

- Drug and alcohol abuse among youth

- Insecurity

- Lack of recreational, sports and cultural facilities to meet the needs of different age groups.

- Lack of training to develop different productive activities

- Limited promotion of productive investments

- Poor accessibility of communities and deteriorating infrastructure of roads

- Low quality of infrastructure of water, sewage, energy and telephone coverage

- Marginalization of population

- Loss of young population, expelling population areas

- Public investment is driven towards the needs of tourists and not for the needs of communities to improve their quality of life.

With regard to changes in the levels of the welfare of the inhabitants living in the area, in the study conducted by Riemann, Santes-Alvarez and Pombo [25] regarding the role of NPA in the local development of the peninsula Baja California, their results show that, on the one hand, these areas represent opportunities for development but on the other, regulations do not allow people to reach higher levels of welfare in terms of use and protection of natural resources. Results of the study demonstrate that welfare levels have not changed despite the resources conducted through several Regional Sustainable Development Programs (PRODERS) for the period studied 1990-2000.

According to the assessment conducted by CONANP-UNAM [21] about PRODERS programs implemented in NPA during 2001 and 2006, results has revealed that changes are incipient on issues like population incomes for those who have been participating in the implementation of programs. However, there have been positive impacts, basically in group creation and involvement in the process, the valuation of effort and development of organization capabilities and self-management, that have allowed them to implement some actions [26]. In both cases, the studies agree that views of changes are unnoticeable with regard to local development. In summary, policies coming from institutions promoting the protection of natural resources, as well as those derived from economic development of tourism have not had a real impact on improving the living standards of the inhabitants in small towns in the region of Valle de los Cirios.

\section{CONCLUSIONS}

The local development scenario of communities living in an NPA will always be influenced by the prime objective of a Natural Area, that is, the protection of ecosystems and environmental quality. Thus, tourism development and human settlements are not likely to experience sustained economic growth to improve a population's standard of living substantially. It has been proven that massive tourism developments based on sun and sand generate higher revenues to regions, and usually are located in coastal areas with lesser environmental constraints. Regarding tourism that can be developed in this NPA, Valle de los Cirios, it should be restricted to nature (eco-tourism, rural tourism and health tourism), which so far has not expressed an economic impact on the region, since it was proposed by FONATUR $[1,2]$. 
Despite planning efforts conducted by different government levels and institutions, management remains the key factor, taking into account technical failures in the formulation of projects, anomalies in compliance with legal procedures, delay in processes to reach consensus, approval of management plans and programs, and financial and political issues due to social rejection.

Within government levels, the weakest chain is municipality and the delegations structure, which have a minimum operating budget that is insufficient to support small communitys' demands and, even more, the quality of public services for tourism.

The project has had several ups and downs from 2000 to 2015 and has gone through three federal administrations and different political parties, that have all tried to rescue the project, but so far have failed to achieve it beyond the first of the four scheduled stages.

\section{REFERENCES}

[1] Fondo Nacional de Fomento al Turismo (FONATUR), Proyecto Escalera Náutica del Mar de Cortés, Documento Básico, 2001, available at http://ccds.semarnat.gob.mx/ regiones/r-no/2002-2004/sesiones_ordinarias/18_sesion_2001/esc-nau-18so-no.pdf

[2] Fondo Nacional de Fomento al turismo (FONATUR). Proyecto Mar de Cortés, available at http://www.fonatur.gob.mx/es/transparencia/LibrosBlancos/3\%20Proyecto\%20 Mar\%20de\%20Cortes.pdf

[3] Secretaría de la Función Pública (SFP) Fondo Nacional de Fomento al turismo (FONATUR), Informe de Rendición de Cuentas de la administración 2000-2006, available at http://www.fonatur.gob.mx/transparencia/abre_contenido_ind.asp?modulo=01TRFON\&cve_sec $=1366 \&$ inciso $=21 \&$ indice $=3 \&$ subindice $=\&$ bases $=$

[4] PO, (Periódico Oficial del Estado de Baja California), Directrices de Desarrollo Urbano Bahía de los Ángeles y Santa Rosalillíta, 11 julio 2003, available at http://www.bajacalifornia.gob.mx/portal/gobierno/legislacion/periodico/110703_N32_SIII.pdf

[5] DOF, (Diario Oficial de la Federación), Área de Protección de Flora y Fauna Silvestre Valle de los Cirios, 7 junio de 2000, available at http://www.conanp.gob.mx/sig/decretos/Acuer-7jun2000.pdf

[6] DOF, (Diario Oficial de la Federación), Área de Protección de Flora y Fauna Islas del Golfo de California, 7 junio 2000, available at http://dof.gob.mx/nota_detalle_popup. php?codigo $=767360$

[7] DOF, (Diario Oficial de la Federación), Reserva de la Biosfera la zona marina conocida como Bahía de los Ángeles, canales de Ballenas y de Salsipuedes, 5 junio 2007, available at https://simec.conanp.gob.mx/pdf_decretos/1_decreto.pdf

[8] DOF, (Diario Oficial de la Federación), Parque Nacional Zona Marina del Archipiélago de San Lorenzo, 25 abril 2005, available at http://dof.gob.mx/nota_detalle.php?codigo $=2034061 \&$ fecha $=25 / 04 / 2005$

[9] DOF, (Diario Oficial de la Federación), Programa Sectorial de Turismo 2013-2018. 13 diciembre 2013, available at http://dof.gob.mx/nota_detalle.php?codigo=5326572\& fecha $=13 / 12 / 2013$

[10] PO, (Periódico Oficial del Estado de Baja California), Plan de Ordenamiento Ecológico del Estado de Baja California, 3 de julio de 2014.

[11] PO, (Periódico Oficial del Estado de Baja California), Directrices Generales de Desarrollo Urbano del Corredor Turístico Bahía de los Ángeles, 19 agosto 2005, available at http://www.bajacalifornia.gob.mx/portal/gobierno/legislacion/periodico/110703_N32_SIII.pdf 
[12] DOF, (Diario Oficial de la Federación). Programa de Ordenamiento Ecológico Marino del Golfo de California, 15 diciembre 2006, available at http://www.semarnat.gob.mx/ archivosanteriores/temas/ordenamientoecologico/Documents/documentos\%20decretados/decretos_2010/decreto_poemgc.pdf

[13] PO, (Periódico Oficial del Estado de Baja California), Programa de Ordenamiento Ecológico Costero Puertecitos-Paralelo 28, 19 de octubre de 2007, available at http:// www.semarnat.gob.mx/archivosanteriores/temas/ordenamientoecologico/Documents/ documentos\%20decretados/actualizacion_2012/acuerdo_p28.pdf

[14] PO, (Periódico Oficial del Estado de Baja California), Programa Regional de Desarrollo Urbano, Turístico y Ecológico del Corredor Costero San Felipe-Puertecitos-Bahía de los Ángeles, 27 diciembre 2010, available at http://www.bajacalifornia.gob.mx/portal/ gobierno/legislacion/periodico/2010/SECC-II-27-12-2010.pdf

[15] DOF, (Diario Oficial de la Federación), Programa de Manejo del Área de Protección de Flora y Fauna Islas del Golfo de California, 17 abril 2001, available at http://dof.gob. $\mathrm{mx} /$ nota_detalle.php?codigo $=767360 \& \mathrm{fecha}=17 / 04 / 2001$

[16] DOF, (Diario Oficial de la Federación). Programa de Manejo del área natural protegida con la categoría de Reserva de la Biosfera la zona marina conocida como Bahía de los Ángeles, canales de Ballenas y de Salsipuedes, 5 noviembre 2013, available at http:// dof.gob.mx/nota_detalle.php?codigo $=5320669 \&$ fecha $=05 / 11 / 2013$

[17] DOF, (Diario Oficial de la Federación), Programa de Manejo del Área de Protección de Flora y Fauna Silvestre Valle de los Cirios, 2 abril 2013, available at http://dof.gob.mx/ nota_detalle.php?codigo $=5294191 \&$ fecha $=02 / 04 / 2013$

[18] DOF, (Diario Oficial de la Federación), Programa de Manejo del Parque Nacional Zona Marina del Archipiélago de San Lorenzo, 20 enero 2015, available at http://www.dof. gob.mx/nota_detalle.php?codigo $=5378952 \&$ fecha $=20 / 01 / 2015$

[19] Sánchez-Crispín, A. \& Propin-Frejomil, E., Transporte y turismo en la península de Baja California, México. Revista Transporte y Territorio, 5, pp. 40-71, 2011.

[20] Rojas-Caldelas, R.I., Planeación del desarrollo rural: elementos del marco regional y local para el caso de Bahía de los Ángeles. Construyendo el futuro. Visiones para un desarrollo rural sustentable en las comunidades de Baja California, ed. A.L. QuintanillaMontoya, Universidad Autónoma de Baja California-Miguel Porrúa, librero-editor: Mexicali, pp. 93-119, 2006.

[21] Zizumbo-Villarreal, L., El turismo en Bahía de los Ángeles. Construyendo el futuro. Visiones para un desarrollo rural sustentable en las comunidades de Baja California, ed. A.L. Quintanilla-Montoya, Universidad Autónoma de Baja California-Miguel Porrúa, librero-editor: Mexicali, pp. 215-251, 2006.

[22] Godínez, A. \& Zavala, C., La conservación del paisaje desértico y costero como vocación de uso del territorio peninsular. Construyendo el futuro. Visiones para un desarrollo rural sustentable en las comunidades de Baja California, ed. A.L. QuintanillaMontoya, Universidad Autónoma de Baja California-Miguel Porrúa, librero-editor, pp. 311-335, 2006.

[23] Casillas-López, B. y G.D. Danemann., Servicios Turísticos. Bahía de los Ángeles: Recursos naturales y comunidad línea base 2007, eds. G.D. en Danemann y E. Ezcurra, Secretaria de Medio Ambiente y Recursos Naturales, Instituto Nacional de Ecología, Pronatura Noroeste A.C. y San Diego Natural Museum: México, D.F, pp. 657-675, 2008, available at http://www2.inecc.gob.mx/publicaciones/download/546.pdf

[24] OTBC, (Observatorio Turístico de Baja California), available at http://observaturbc.org/ 
[25] Riemann, H., Santes-Alvarez, R.V. \& Pombo, A., El papel de las áreas naturales protegidas en el desarrollo local El caso de la península de Baja California. Gestión y Política Pública, 20(1), pp. 141-172, 2011.

[26] Universidad Nacional Autónoma de México (UNAM) Comisión Nacional de Áreas Naturales Protegidas (CONANP), Evaluación de pertinencia, gestión e impacto socioeconómico y ambiental del ejercicio 2006 del Programa de Desarrollo Regional Sustentable, PRODERS, Informe final, available at http://www.conanp.gob.mx/acciones/pdf_2010/EVAL\%207\%20INFORME_FINAL_CONSISTENCIA_ANEXOS.pdf

[27] Secretaria de Medio Ambiente y Recursos Naturales (SEMARNAT) Comisión Nacional de Áreas Naturales Protegidas (CONANP), Programa de Turismo en ANP 2006 2012, Estrategia Nacional para un Desarrollo Sustentable del Turismo y la Recreación en las ANP de México, available at http://www.conanp.gob.mx/pdf_publicaciones/ TurismoEstrategia.pdf

[28] Comisión Nacional para el Conocimiento y Uso de la Biodiversidad (CONABIO). Sitios de manglar con relevancia biológica y con necesidades de rehabilitación ecológica, Ficha de caracterización Bahía de los Ángeles, available at http://www.conabio.gob. $\mathrm{mx} /$ conocimiento/manglares/doctos/caracterizacion/PN01_Bahia_de_los_Angeles_ caracterizacion.pdf

[29] Alianza para la Sustentabilidad del Noroeste Costero, A.C. (ALCOSTA). ¿DESARROLLO TURÍSTICO REGIONAL? Monitoreo de los desarrollos turísticos e inmobiliarios costeros del noroeste de México 2005-2006, The David and Lucile Packard Foundation, Fondo para la Conservación del Golfo de California y National Wildlife Federation, available at http://www.frontline.lunasexta.org/alcosta.pdf 